\title{
THE FRICTION FACTOR DEPENDENCE ON THE LOAD AND REVOLUTIONS IN SLIDING BEARINGS WITHOUT RELUBRICATION
}

\author{
Pavel Beňo, Ján Marienčík, Ján Turis, Dražan Kozak, Pejo Konjatić
}

Original scientific paper

This article is focused on experimental research of the friction factor in sliding bearings without relubrication. The research includes study of friction factor values and their comparison depending on load and revolutions measured on sliding pairs, consisting of a sliding bearing and a shaft, without relubrication. The result of this experiment is an evidence of values measured reflecting the sliding pair actions under operation conditions. All the represented measured results and load conditions of each bearing are presented via graphs.

Keywords: friction; friction factor; frictional force; normal force

Ovisnost faktora trenja o opterećenju i broju okretaja kod kliznih ležaja bez ponovnog podmazivanja

Izvorni znanstveni članak

Ovaj članak se bavi eksperimentalnim istraživanjem faktora trenja kod kliznih ležaja bez ponovnog podmazivanja. Istraživanje uključuje određivanje iznosa faktora trenja i usporedbu ovisno o opterećenju i broju okretaja mjerenih na kliznom paru bez ponovnog podmazivanja koji se sastoji od kliznih ležaja i vratila. Rezultat ovog pokusa je pokazatelj izmjerenih vrijednosti kliznog para u radnim uvjetima. Sve slike mjerenja i uvjeta opterećenja za svaki ležaj predstavljene su pomoću dijagrama.

Ključne riječi: faktor trenja; normalna sila; sila trenja; trenje

\section{Introduction}

The sliding mounting operation in particular areas can be defined by the friction factor value, wear factor and by other operation factors. In case of the sliding friction the friction factor $f$ is determined by the friction tangential force and load normal force ratio. The factor $f$ is an invariable for the used sliding materials when working at particular environmental conditions only; it changes according to environmental and material changes.

The friction factor is defined as energy needed for friction loss balance and overall energy given to the system ratio [1, 2]. Bearings can be lubricated with satisfactory long lasting lifespan and reliability thanks to modern methods of operations when manufacturing bearing materials, along with the deeper understanding of lubrication process. The research aimed at finding new composite bearing materials with low coefficient friction values and wear has been carried out recently [3].

The aim of this article is to ascertain and compare friction factors under different operational conditions and, at the same time, to ascertain how the load value and revolutions influence the value of friction factor.

\subsection{Adhesive friction theory}

The base for the adhesive friction theory is the initial, so called simple theory of adhesive friction of pure metals, created by Bowden and Tabor [4].

The base of this theory is a fact that two metal surfaces pressed to each other are in contact with their roughness peaks only, and because of this very small contact area the contact pressure is very high. Relief malformation and relief material flow in the contact area together with contact area growing is caused by this pressure and this lasts until the real contact area is large enough to take the load over [1].

According to the theory, the takeover of the force by sliding friction is provided by adhesive connections that emerge by the activating of intermolecular effects and under the influence of extremely high local and actual pressure on the micro roughness peaks that are in contact [5].

The theory was based on the following two statements:

a) The friction force is dependent on real area of contact between two bodies.

b) The friction force is dependent on shearing strength of adhesive bond formed between two bodies at tip of asperities [6].

The research in this field has been mainly focused on two orientations. Firstly, the friction has been ascribed to adhesion, which means, the research has been focused on the origins of the adhesion with the atomistic approach. A contribution to this viewpoint has been given by Landheer and de Gee, who showed that boundary lubrication, is able to consistently reduce friction without affecting surface plastic deformation.

Other researchers consider that surface deformations play an outstanding role in determining friction. Suh and co-workers recognize three contributions to friction: asperity deformation, adhesion and ploughing [7]

This relation is valid for an ideal flexible-textured material, in which the malfunction does not change any physical properties:

$S_{\mathrm{d}} \cdot p_{\mathrm{P}}=F_{\mathrm{n}}$,

where $S_{\mathrm{d}}$ is the actual contact area and $p_{\mathrm{P}}$ is the pressure on this area at its peak value with the reach of the sliding limit, and $F_{\mathrm{n}}$ is the normal force [1]. When the normal 
force $F_{\mathrm{n}}$ is increasing the actual contact force is increasing as well, thanks to the increase of the contact numbers [8]. A high adhesion is assumed when establishing the metal to metal contact, where there are connections, so called cold welds (metal and covalent bonds). The shear stress $\tau_{\mathrm{p}}$ for the slide induction towards the breaking point of the material in one of the peaks in the weld areas is needed to create mutual relative movement of surfaces. It is also assumed that a few of the peaks could groove - furrow the opposite surface, and the friction force is:

$$
F_{\mathrm{t}}=S_{\mathrm{d}} \cdot \tau_{\mathrm{p}}+F_{\mathrm{tb}}
$$

where $F_{\mathrm{tb}}$ is tangential force needed for the grooving furrowing, more precisely, ploughing of softer surface by the relatively moving hard roughness peaks of the second body surface. Using experiments with clean and unlubricated metal surfaces it has been discovered that:

$$
F_{\mathrm{tb}}<<S_{\mathrm{d}} \cdot \tau_{\mathrm{p}},
$$

and that is the reason why this force is not taken into account. Then it can be precisely assumed:

$$
F_{\mathrm{t}} \approx S_{\mathrm{d}} \cdot \tau_{\mathrm{p}}=\frac{F_{\mathrm{n}} \cdot \tau_{\mathrm{p}}}{p_{\mathrm{P}}},
$$

and for the friction factor:

$$
f=\frac{F_{\mathrm{t}}}{F_{\mathrm{n}}}=\frac{\tau_{\mathrm{p}}}{p_{\mathrm{P}}},
$$

Ratio $\tau_{\mathrm{p}} / p_{\mathrm{P}}$ can be considered invariable for most of the metals and the Eq. (5) explains why the metal friction factor is rarely changing even in a case when mechanical properties of metals, e.g. hardness, are approximately changed $[1,9]$.

Bowden and Tabor differentiate 3 types of the friction and wear mechanism depending on the respective shear measurements:

The $1^{\text {st }}$ case $\tau_{\mathrm{p} 2}<\tau_{\mathrm{p}}<\tau_{\mathrm{p} 1}$ - when the softer body is worn, its parts are settling on the harder body,

The $2^{\text {nd }}$ case $\tau_{\mathrm{p} 1}, \tau_{\mathrm{p} 2}<\tau_{\mathrm{p}}-$ when both bodies are worn, and separated material parts are settling on the opposite bodies,

The $3^{\text {rd }}$ case $\tau_{\mathrm{p} 1}, \tau_{\mathrm{p} 2}>\tau_{\mathrm{p}}-$ micro welds are disrupted without any material particle transfer from the frictional bodies.

$\tau_{\mathrm{p} 1}$ is the shear strength of the basic frictional body, mostly the body with the higher surface hardness, $\tau_{\mathrm{p} 2}$ is the shear strength of the second body, and $\tau_{\mathrm{p}}$ is the shear strength of micro welds (adhesive connections) [5].

\section{Measurement procedure}

The main aim of experiment was to analyse and compare friction factor values depending on load and revolutions measured on sliding pairs without relubrication consisting of a sliding bearing and a shaft. The measure has been made with the measuring tool Tribotester M'12.
Two types of identically dimensioned sliding bearings were the measured samples (Fig. 1) made from different materials:

- Outer diameter of a bearing: $D=50 \mathrm{~mm}$

- Inner diameter of a bearing: $d=40 \mathrm{~mm}$

- Width of a bearing: $B=40 \mathrm{~mm}$

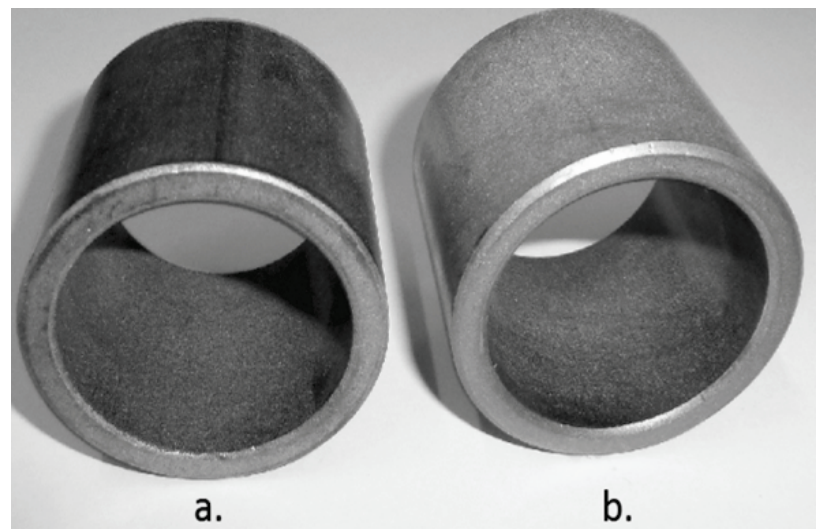

Figure 1 Sliding bearings used in the experiment: a - Bearing A, highspeed bearing - bronze matrix; $b$ - Bearing B, self-lubricating bearing sinter bronze

For measuring purpose, sliding bearing was set into the measuring head alongside with the temperature sensor and put on the revolving shaft (Fig. 2).

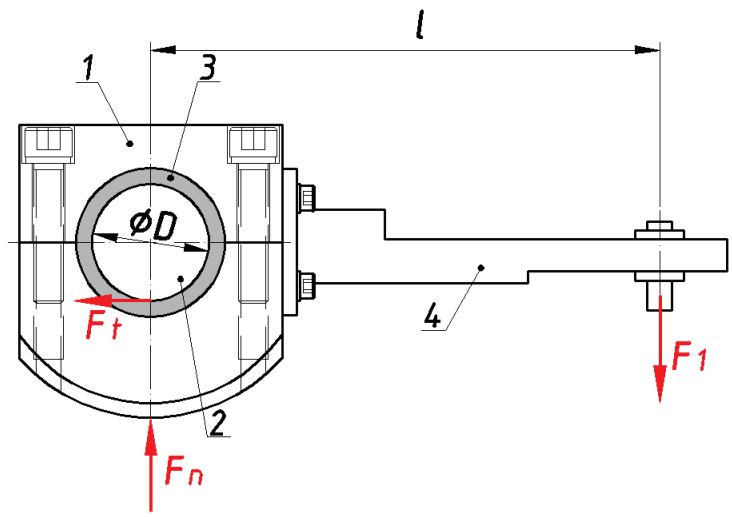

Figure 2 Measuring principle (1 - measuring head, 2 - shaft, 3 - sliding bearing, 4 - arm)

The shaft was made from material E 335 (11 600) manufactured with the tolerance $\mathrm{f} 7$. Afterwards, the shaft has been rotated by the electric motor and frequency transformer on chosen revolutions.

The load on measuring head has been generated by the stepping motor and transmission mechanism. The load force (normal force $F_{\mathrm{n}}$ ) is measured by the force sensor P20 (working range up to $15 \mathrm{kN}$ ). Force $F_{\mathrm{n}}$ generates friction force $F_{\mathrm{t}}$, which can be calculated on the basis of moments balance according to the relation (6) by the force $F_{1}$ measured by the force sensor (working range up to $0,22 \mathrm{kN}$ ) and the length of arm, where this force is active [10].

$F_{1} \cdot l=F_{\mathrm{t}} \cdot \frac{D}{2}$,

Number $($ No. $1 \div 16)$ of measurements on two types of the sliding bearings has been made within the experiment (Tab. 1 and 2). The aim of this experiment 
was to obtain the friction factor dependence on the changing normal force, and friction factor change depending on the revolutions.

When measurement was done with invariable revolutions of $n=150 \mathrm{~min}^{-1}$, the bearing was loaded sequentially by the normal force of $0,75,1,1,25$ and 1,5 $\mathrm{kN}$. The shaft was rotated on chosen revolutions 75,100 , 125, $150 \mathrm{~min}^{-1}$ when measurement was done with invariable load $F_{\text {n. }}$.

Table 1 Measurement done on the bearings Type A

\begin{tabular}{|c|c|c|c|c|}
\hline \multirow{2}{*}{$\begin{array}{c}\text { Revs } \\
n=150 \mathrm{~min}^{-1}\end{array}$} & \multicolumn{4}{|c|}{ Load $F_{\mathrm{n}} / \mathrm{kN}$} \\
\cline { 2 - 5 } & 0,75 & 1 & 1,25 & 1,5 \\
\cline { 2 - 5 } & No. 1 & No. 2 & No. 3 & No. 4 \\
\hline \multirow{2}{*}{$\begin{array}{c}\text { Load } \\
F_{\mathrm{n}}=1,5 \mathrm{kN}\end{array}$} & \multicolumn{4}{|c|}{ Revs $n / \mathrm{min}^{-1}$} \\
\cline { 2 - 5 } & 75 & 100 & 125 & 150 \\
\cline { 2 - 5 } & No. 5 & No. 6 & No. 7 & No. 8 \\
\hline
\end{tabular}

Table 2 Measurement done on the bearings Type B

\begin{tabular}{|c|c|c|c|c|}
\hline \multirow{3}{*}{$\begin{array}{c}\text { Revs } \\
n=150 \mathrm{~min}^{-1}\end{array}$} & \multicolumn{4}{|c|}{ Load $F_{\mathrm{n}} / \mathrm{kN}$} \\
\cline { 2 - 5 } & 0,75 & 1 & 1,25 & 1,5 \\
\cline { 2 - 5 } & No. 9 & No. 10 & No. 11 & No. 12 \\
\hline \multirow{2}{*}{$\begin{array}{c}\text { Load } \\
F_{\mathrm{n}}=1,5 \mathrm{kN}\end{array}$} & 75 & 100 & 125 & 150 \\
\cline { 2 - 5 } & No. 13 & No. 14 & No. 15 & No. 16 \\
\hline
\end{tabular}

\subsection{Tested sliding bearings characteristics}

Bearings A, high-speed bearings made from the bronze matrix - these bearings do not require relubrication or other maintenance, and they are made of bronze matrix where pores are impregnated by the mineral oil. They are made in accordance with the standard ISO 2795 and are used for rotation movement. The basic material is SINT A50 and the pores' volume is 2,8 \%. This type of bearings has high sliding speed, low friction and does not need any maintenance.

Bearings $B$, self-lubricating bearings made of sinter bronze - these bearings are used for restricted lubrication conditions. They are made by powder metallurgy from metal powders with different size and shape of particles. Porous metal with porosity of $2,5 \%$ is saturated with oil and this functions as a lubricant for the sliding knot. Basic bearing material is $\mathrm{Cu}$ with the admixture of $\mathrm{Sn} 9 \div 11 \%$, and $\mathrm{C} 0,2 \%$ and other elements $2 \%$.

\subsection{Measuring tool characteristics}

Testing device Tribotester M'12 (Fig. 3) is used to obtain parameters and properties of sliding bearings, hydrodynamic lubricated sliding bearings, and porous bearings saturated with the lubricant, as well as other sliding elements very quickly.

This device can simulate working conditions of a sliding knot or perform trial testing of sliding materials at standard dimensions of tested bearings and shafts. It is able to work at invariable speed and specific load, and variable parameter can be set manually or by the preset programme. This device enables testing of the terminal load (jam test), test of terminal speed (speed jam test), load capacity test for determination of $p-v$ diagram, and lifespan test.

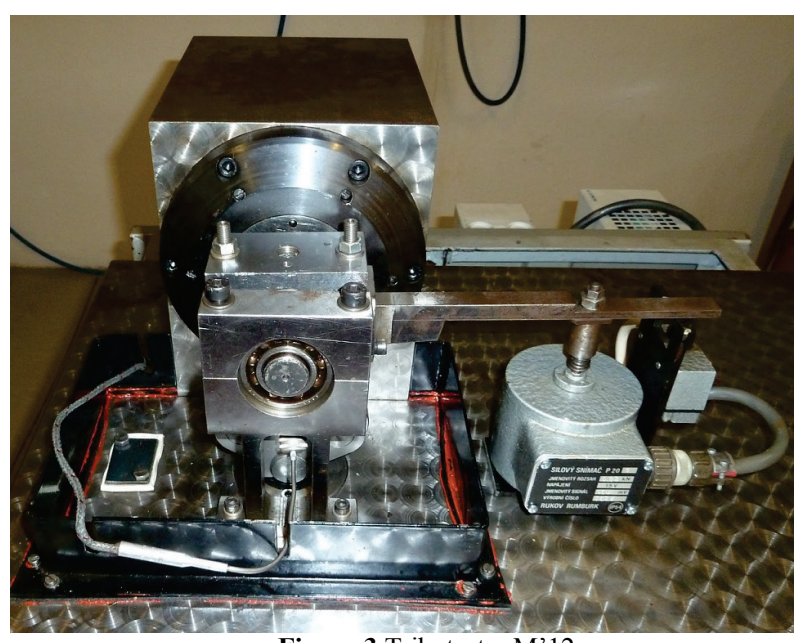

Figure 3 Tribotester M'12

\section{Results and discussion}

Measurement on two types of common sliding bearings without relubrication was performed during this experiment. The aim was to obtain friction factor values at chosen load and revolutions. The results were evaluated with linear regression. They were expressed by connecting line of trend and determination coefficient $\mathrm{R}^{2}$ (Fig. 4, 5, 6, 7). The friction factor dependence on time is shown in graphs.

\subsection{Bearings - Type A}

First, 4 equal A-type bearings were tested. The aim was to obtain the friction factor by the changing load and invariable $n=150 \mathrm{~min}^{-1}$. The bearings were sequentially loaded by normal force stated in Tab. 1. Resulting progress of the friction factor can be seen in Fig. 4.

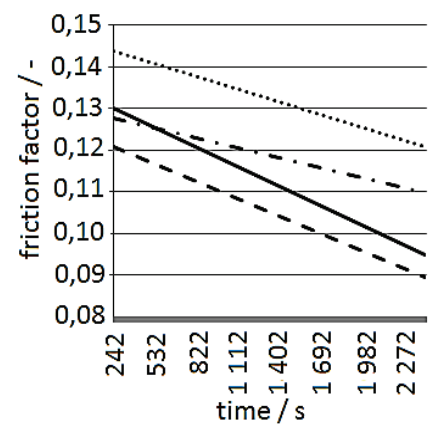

- $\mathrm{f} 1(\mathrm{Fn}=1,5 \mathrm{kN}), \mathrm{y}=-8.10^{-5} \mathrm{x}+0,130 \mathrm{R}^{2}=0,348$

- - $\mathrm{f} 2(\mathrm{Fn}=1,25 \mathrm{kN}), \mathrm{y}=-7.10^{-5} \mathrm{x}+0,120, \mathrm{R}^{2}=0,317$

- - $\mathrm{f} 3(\mathrm{Fn}=1 \mathrm{kN}), \mathrm{y}=-4.10^{-5} \mathrm{x}+0,127, \mathrm{R}^{2}=0,541$

........ $\mathrm{f} 4(\mathrm{Fn}=0,75 \mathrm{kN}), \mathrm{y}=-5.10^{-5} \mathrm{x}+0,144, \mathrm{R}^{2}=0,079$

Figure 4 The friction factor dependence on normal force and with invariable revolutions

The intensity of pressure force $F_{\mathrm{n}}$ had no influence on the friction factor. It is caused by the friction force dependence on normal force and this fact can be read from the measured values. This means that the friction force/normal force ratio is almost equal even with the growing load. The factor values were in the range from 0,14 to 0,10 and were of decreasing nature with all the load values.

The next experiment task was to obtain the influence of revolutions on the final friction factor with invariable 
load $F_{\mathrm{n}}=1,5 \mathrm{kN}$. The friction factor values were sequentially measured according to Tab. 1 with different revolutions seen in Fig. 5. The friction factor value has not been significantly changed depending on revolutions - this can be read from the measured values.

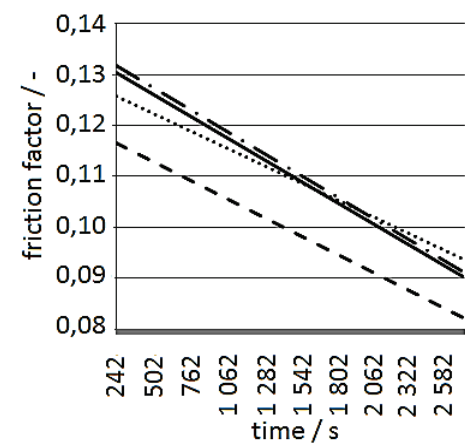

- f5 (Fn=150 $\left.\mathrm{min}^{-1}\right), y=-8 \cdot 10^{-5} x+0,130 R^{2}=0,348$

- $f 6\left(n=125 \mathrm{~min}^{-1}\right), y=-7.10^{-5} x+0,116, R^{2}=0,409$

- $f 7\left(n=100 \mathrm{~min}^{-1}\right), y=-8.10^{-5} x+0,131, R^{2}=0,541$

.... f8 $\left(n=75 \mathrm{~min}^{-1}\right), y=-7.10^{-5} x+0,125, R^{2}=0,440$

Figure 5 The friction factor dependence on revolutions with invariable load

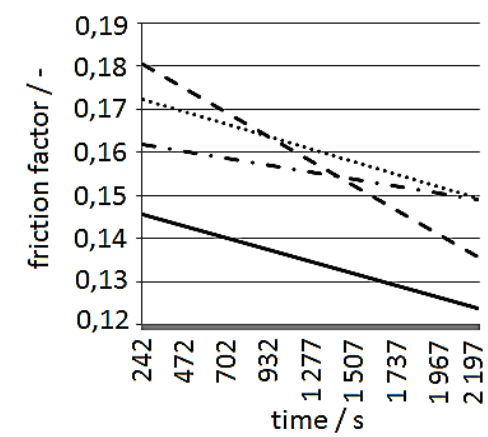

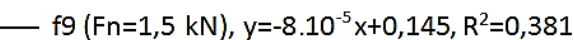

- - f10 (Fn=1,25 kN), y=-0,001x+0,180, $R^{2}=0,569$

-. f11 (Fn=1 kN), $y=-3.10^{-5} x+0,161, R^{2}=0,098$

…... f12 (Fn=0,75 kN), v=-6.10 $0^{-5} x+0.172, R^{2}=0.138$

Figure 6 The friction factor dependence on normal force at invariable revolutions

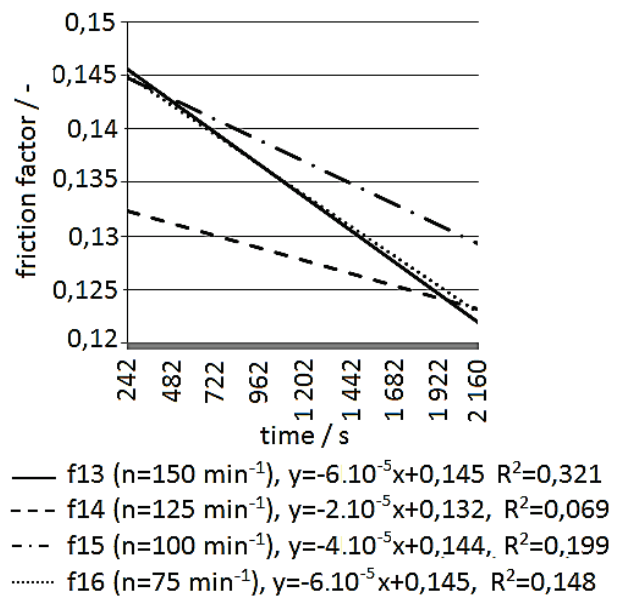

....... f16 $\left(n=75 \mathrm{~min}^{-1}\right), y=-6.10^{-5} x+0,145, R^{2}=0,148$

Figure 7 The friction factor dependence on revolutions at invariable load

\subsection{Bearings - Type $B$}

The measurement on the bearing - type B has been performed with the aim to obtain friction factors by invariable revolutions shown in Tab. 2. It is shown that the variance of the friction factor values with decreasing tendency (Fig. 6) is more noticeable with the Type B bearings.

However, according to the measured values, it is obvious that the amount of the pressure load has no significant effect on the friction factor. The change of friction factors dependant on revolutions at invariable pressure load can be seen in Fig. 7.

\section{Conclusion}

The fact that the normal load and revolution values had no significant effect on the friction factor value when the maximum load allowed for the sliding bearing working without relubrication has not been exceeded, can be seen from the above graphs. The friction factor value difference under different operational conditions was not significant. The decrease of the friction factor value is being noticed at all measurements. This is caused by the sliding knot running-in.

This can be explained by the Amontons' second friction principle. The main idea of this principle is that the friction force is directly proportional to normal load among bodies. This means, the most important elements that influence the friction factor are material properties of the sliding knot. However, the load and revolution values influence the sliding surfaces' wear and consequently the sliding bearing's and shaft's lifespan significantly. The increase of load and revolution values causes the temperature increase in the contact area and this has a negative effect on the operation and lifespan of tribological elements.

According to the acquired values it is possible to assume that under specific conditions with low revolutions and low load values (or by seesaw motion) hydrodynamically or hydrostatically lubricated bearings can be replaced by sliding bearings without additional relubrication. The research of sliding mountings without lubrication has an enormous meaning because of the growing ecological and environmental requirements. The experts have not had enough complex data and analysis on contact pairs' state and performance at dry and terminal friction.

\section{Acknowledgments}

The article has been written on the basis of research intention and solution of the research grant projects: KEGA No. 018TU Z-4/2014 "Implementation of Educational Methods for Enhancement of the Education in Field of Technical Mechanics" and VEGA No. 1/0676/14" Technical and ecological research aimed at reducing the adverse of the operation of machinery on forest land and water" by the Ministry of Education, Science, Research and Sport of the Slovak Republic.

\section{References}

[1] Barysz, I.; Čillík, L.; Žiačik, A.; Pfliegel, M. Klznéuloženie, konštrukčné a teoretickériešenia. VŠDŠ v Žiline, Žilina, 1995.

[2] Šafr, E. Tribotechnika, STNL - Nakladatelství technické literatury, Prague, 1984. 
[3] Shigley, J. E.; Mischke, CH. R.; Budynas, R. G. Konstruování strojních součástí. VUTIUM, Brno, 2010.

[4] Bowden E. P.; Tabor D. The Friction and Lubrication of Solids, Vol. I, Clarendon Press, Oxford, 1954.

[5] Blaškovič, P.; Balla, J.; Dzimko, M. Tribológia. ALFA, Bratislava, 1990.

[6] Bera, B. Adhesional Friction Law and Adhesive Wear Law of Micromechanical Surface Contact. // International Journal of Engineering Research and Applications. 2, 5(2012), pp. 404-411.

[7] Straffelini, G. A simplified approach to the adhesive theory of friction. // Wear. 249, 1-2(2001), pp. 79-85. DOI: 10.1016/s0043-1648(01)00524-5

[8] Czichos, H.; Habig, K. H. Tribologie - Handbuch, Mercedes Druck, Berlin, 2010. DOI: 10.1007/978-3-83489660-5

[9] Marienčík, J.; Turis, J.; Beňo, P.; Remperová, M. Kontaktné procesy pri elastickom a plastickom kontakte $\mathrm{v}$ tribologickom systéme. // Acta facultatis technicae Zvolen. 17, 3(2012), pp. 123-130.

[10] Marienčík, J.; Turis, J.; Beňo, P. The tribological characteristics of the sliding bearing. // International journal of interdisciplinarity in theory and practice. 1, 2(2013), pp. 90-93.

\section{Authors' addresses}

\section{Pavel Beňo, Doc. Ing. PhD}

Faculty of Environmental and Manufacturing Technology, Technical University in Zvolen,

Študentská 26, 96001 Zvolen, Slovak Republic

E-mail: pavel.beno@tuzvo.sk

\section{Ján Marienčik, PhD}

Faculty of Environmental and Manufacturing Technology, Technical University in Zvolen,

Študentská 26, 96001 Zvolen, Slovak Republic

E-mail: jmariencik@gmail.com

\section{Ján Turis, PhD}

Faculty of Environmental and Manufacturing Technology,

Technical University in Zvolen,

Študentská 26, 96001 Zvolen, Slovak Republic

E-mail: jan.turis@tuzvo.sk

\section{Dražan Kozak, Prof. dr. sc.}

Mechanical Engineering Faculty in Slavonski Brod,

J. J. Strossmayer University of Osijek,

Trg Ivane Brlic Mazuranic 2, 35000 SlavonskiBrod, Croatia

E-mail: dkozak@sfsb.hr

Pejo Konjatić, Doc. dr. sc.

Mechanical Engineering Faculty in Slavonski Brod,

J. J. Strossmayer University of Osijek,

Trg Ivane Brlic Mazuranic 2, 35000 SlavonskiBrod, Croatia

E-mail: pekon@sfsb.hr 